\title{
Development of nautical tourism: islands development motivator
}

\author{
N. Jolić ${ }^{1}$, N. Perko ${ }^{2} \&$ Z. Kavran ${ }^{1}$ \\ ${ }^{I}$ Faculty of Transport and Traffic Sciences, University of Zagreb, Croatia \\ ${ }^{2}$ Ministry of the Sea, Transport and Infrastructure, Croatia
}

\begin{abstract}
The Republic of Croatia, as a Mediterranean country with an indented coast has an archipelago with more than a thousand islands, which is a recognizable market potential of Croatian tourism. Because of the natural values, a particularly valuable and successful part of Croatian tourism and the potential of islands development is the development of nautical tourism. The indicators of the quality of nautical tourism and the nautical tourism quality management system have not been sufficiently studied yet. The basic principle of nautical tourism development management is the principle of sustainable development, which in a compromised and balanced manner is a pre-condition for analyses of the need to preserve the natural environment and the need for economic development. Strategic documents of the Republic of Croatia define "nautical tourism as a special type of tourism which apart from navigation in private organization - cruising by one's own or leased vessel with onboard accommodation and/or sleeping of tourists, includes also cruises in the organization of vessel owners and travel agencies with accommodation and/or sleeping of tourists onboard these vessels, and navigation of tourists onboard vessels for the purpose of other forms of holidays and recreation (fishing, diving)." The paper will implement the multi-criteria decision-making methodology in selecting the criteria and sub-criteria of the nautical tourism development model. The influence of criteria, sub-criteria and alternatives on the function of objectives, i.e. the development function of islands, and the assessment of influence of factors will be determined. The research results are based on the expert assessment and input data on the system (elements, characteristics) of nautical tourism of the Republic of Croatia.
\end{abstract}

Keywords: nautical tourism, islands development. 


\section{Introduction}

A nautical tourism port is a tourist object, which, from the business, spatial, construction and functional aspects, makes an entirety for satisfying the requirements of nautical tourism and nautical tourists - boaters. In countries with a developed nautical tourism economy, an increased number of nautical tourism ports have been observed. It is therefore reasonable to expect the increase of their impact to the environment (Kasum et al. [1]).

Nautical tourism is exceptionally suitable for expanding Croatia's tourism offer. Although its share in the country's tourism industry is still low with regard to its potentials, the development of nautical tourism would automatically change the way future tourists perceive Croatia; no longer would it be a country for mass tourism, but rather a tourist country geared to the needs of modern tourists (Gračan [2]).

Croatian Tourism Industry Law defines nautical tourism as navigation and stay of nautical tourists on their vessels and in nautical ports for the purpose of relaxation and recreation (Bartoluci and Čavlek [3]).

Nautical tourism can also be defined as the total of relationships and services resulting from navigation and stationed sojourn of domestic and foreign tourists on the sea and on the water organised by the tourists themselves or by somebody else as well as navigation for the purpose of relaxation, leisure and fun (Jadrešić [4]).

Tourist services available at marinas catering to nautical tourists include [5]:

- Leasing of berths for sailing vessels and nautical tourists who live on board.

- Leasing of sailing vessels for holiday and recreational use (charter, cruising and similar),

- Reception, safe-guarding and maintenance of sailing vessels.

- Provision of stock (water, fuel, supplies, spare parts, equipment and similar).

- Preparation and keeping sailing vessels in order.

- Providing information to nautical enthusiasts (weather forecasts, nautical guides etc.)

- Leasing of water scooters, jet skis, and other water equipment.

Although at first glance nautical tourism can seem to have a highly mobile nature tied to a single form of sports and recreational activities on a vessel, due notice should be given to the significance of its stationary component, as one of the most important factors in developing and improving this form of tourism. This stationary component consists of primary receiving facilities and supplementary facilities (Bartoluci and Čavlek [3]).

Having in mind Croatian littoral zone with its attractive coast and islands, it can be said that nautical tourism is absolutely authentic and distinctly recognizable Croatian "tourist product". Croatia has ideal conditions for nautical tourism development, and it has a great number of advantages such as good coastline indebtedness', great number of well arranged and sheltered harbours, better geographical position in relation to countries that nautical tourists come from, preserved nature, and clean sea (Favro and Saganić [6]). 
The main middle-term goals of tourism development in Croatia are to increase the revenue from tourism, to create employment and raise the standard of living, to increase the positive effects of tourism and tourist spending on the Croatian economy, to raise the quality of service, to offer new attractions, to extend the tourist season and create.

In this paper application proposal of new concept of security levels in nautical ports is defined for future development and modernization of nautical ports. Based on predefined criteria, multi-criteria modelling of security levels for all groups of nautical ports will be explained and security levels defined.

\section{Sociological-economic effects of the development of nautical tourism}

Special importance, in increasing overall economic effects of nautical tourism, is given to the improvement of social and economic living conditions for local inhabitants of coastal and islands areas. According to Robinson [7], interdependence between the development of nautical tourism and the development of local community becomes an increasingly important link in the development of nautical economy. By defining development strategy for nautical tourism in Croatia, to be based upon the principles of sustainable development, necessary conditions will be established for achieving the following goals (Favro and Saganić [6]):

- Tourism as economic sector has benefited most from the development of one its segment-nautical tourism. All positive effects to be attached to nautical tourism can also be attached to tourism in general.

- Catering industry through the development of nautical tourism has been given a chance of expansion and specialization. If it had not been for the growth of nautical tourism, it is unlikely that small island restaurants with famous delicacies would have ever developed in the most attractive nautical destinations. Many individuals have not only expanded their existing catering capacities, but also invested into new ones. Small, almost abandoned island localities have been restored to life and reconstructed. The number of those who reconstruct the neglected heritage - buildings and crops - grows every day as a result of increasing visits of tourists, especially on islands.

- Accommodation capacities - Nautical tourism has had an indirect influence on increased accommodation capacities in the coastal zone and on islands. Some leisure mariners, predominantly higher spending ones, wishing to experience the stunning beauty of the Croatian archipelago, prefer luxury hotels in picturesque environment rather than sleeping onboard their vessels. In this way, nautical tourism has influenced an increase in accommodation capacities in the seaside places and on islands.

- Service activities - It has already been mentioned that nautical tourism encouraged the development of many service activities which are either directly or indirectly associated with the need to provide different services to leisure mariners. This particularly refers to fisheries whose development is 
indirectly influenced by an increased demand for fish and consumption of seafood in restaurants, for different nautical services, etc. provided.

- Greater opportunities - for the employment of local labour (occasional, parttime, seasonal or permanent), consequently influencing increase in the living standard, and prosperity of families in general, providing opportunity for the development and revival of different activities specific for particular regions.

- Direct and indirect effects on different activities - Direct effects of nautical tourism are first of all connected with employment of local labour, encouragement of different service activities linked with the need to provide services to leisure mariners (servicing vessels and engines, equipment, catering, supply, etc.), while indirect effects are many. Interest for cultural events and sightseeing tours of coastal and island places should also be emphasized.

- Short-term consequences and influences - It may be said that the development of nautical tourism has had a short-term influence and specific economic and social consequences on the local and wider environment. First of all, it encouraged the development of many accompanying activities, whose development started soon after the beginnings of nautical tourism (first services, initial employment of local labour, expanding the existing catering facilities and opening new ones, etc.).

- Long-term consequences and influences - Most important long-term consequences and influences of the development of nautical tourism are as follows:

- restructuring and evaluating new development options in a particular county, community or place, as well as at the state level, starting from some traditional aspects (industry, manufacturing industry, shipbuilding) to the development based upon nautical tourism

- development - of economic activities directly or indirectly connected with nautical tourism as chief development potential - nautical economy (Favro [8]).

\section{AHP modelling}

In planning of security of nautical ports there are numerous alternatives for the system changes and improvement. The larger number of alternatives, the more complex the issue is, because it is necessary to take into account all alternatives and select the best one or the one being the closest to the set goal. In examining of alternatives it is necessary to define criteria leading to the set goal and potential impacts on the system changes. Each alternative has its own specificities that create additional difficulties in decision making. A good planning expert, i.e. decision maker on development of the marina system must have vision of the future, must select the alternative being sufficiently flexible to enable potential modifications to be performed.

Analytical hierarchy process, as a part of operational research, represents a structured approach that enables integration of logic and intuition in the process of decision making in the way adjusted to human perception and computer logic. 
The process is performed in three basic steps:

1. Decomposition of complex problem/decision into hierarchical structure

2. Determination of elements priorities at each level

3. Synthesis of results

Defining alternatives made in the system and criteria for their selection to attain the main goal of research represent security levels for nautical ports (Jolic et al. [9]). Mathematical model of the problem analysis is based on the individual comparison at each hierarchy level and impact of alternatives on the lowest level of hierarchy. It gives pair wise - comparison matrix. In the process of comparison, elements on the same hierarchy level must have the same significance and if such a requirement is not met, they have to be allocated into different hierarchy levels. By the process of pair wise comparison of the elements on the same hierarchy level, it is determined whether the elements are of equal significance or one of them is of higher significance compared with any other element. Such a process gives the priority values for all elements on each level in relation to a criterion on the first higher level. If among values obtained in such manner there are elements having no considerable significance in relation to the objective, they can be eliminated from further consideration in order to simplify the model. Total priority for each of managing measures, i.e. alternative is determined by combining of priorities of each hierarchy level. The alternative having the highest total will be selected.

\section{Multi-criteria security level modelling for nautical ports}

Multi-criteria modelling process defines security levels in marine as follows: Security Level I, Security Level II and Security Level III (Jolić et al. [9]). Each

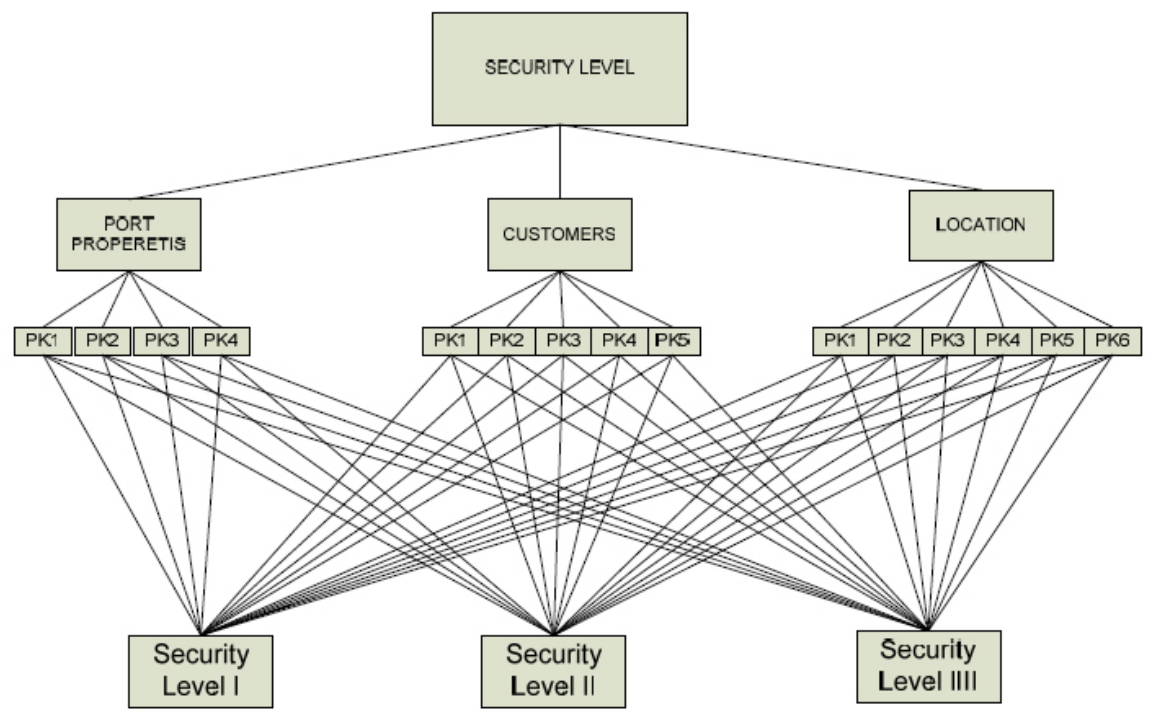

Figure 1: AHP model of marina security levels. 
level is presented by recognized technical characteristics and defined technological activities; this determination serves as a platform for ICT implementation procedures. Research results are vital benefit for port managers dealing with port capacities planning activities and port market definition. Model for security level definition is presented on figure 1 .

Port properties criteria includes sub criteria's as number and the position of emergency boxes with extinguishers, throw lines, first aid kits, thermal blankets, lifebelts and emergency ladders, smoke detectors, carbon monoxide detectors, condition of electrical wiring, storm emergency alarming systems, fuel and pipelines, maintaining areas, spaces for children to play etc.

Customers' criteria include elements as yearly number of visitors but also safety and security customers' requirements with regular feedback information from users. Table 1 shows basic checklist of things users look for in marinas regarding security.

Security levels include different organization characteristics including security regulations, guide lines and equipment. So that based on defined criteria security levels can be defined for every marina.

\section{Conclusion}

Nautical tourism is one of the most attractive and prosperous forms of Croatian tourism. Because of the natural values an especially valuable and successful part of the Croatian tourism and potential of islands development is the development

Table 1: Users' security and safety checklist.

Is the marina attractive and well maintained?

Is someone checking your boat on a regular basis?

Is the pump-out facility in working order and easily accessible?

Are the docks, piers, and pilings in good condition?

Are the dock cleats large enough for your boat, and securely attached?

Is the electrical system up to date?

Are there life rings, with lines attached, at 200-foot intervals on the docks?

Are emergency phone numbers (fire, ambulance, police, coastguard) clearly posted?

Are there fire extinguishers where needed?

Are "NO SMOKING" signs posted on the fuel dock?

Is there sufficient parking?

Are the restrooms, laundry facilities, and pool (if the marina has one) kept locked and only available to marina residents and guests?

Is the marina in a dangerous or safe neighbourhood?

If dogs are allowed, is there a designated Dog Walk? 
of nautical tourism. The quality of service of a marine represents a criterion which is essential in the selection of a port and islands development process. According to defined main middle-term goals of tourism development in Croatia high level of port service is to be developed, i.e. high level of safety. According to the carried out research, single requirements have been identified, set by the users of the ports of nautical tourism, expecting their fulfilment. Consequently, three levels of port security have been defined, i.e. three security levels, and the multi-criteria modelling procedure has been presented. Special emphasis is on the application of new technologies in order to increase safety and security of the yachtsmen, ships, and the port infrastructure.

\section{References}

[1] Kasum, J, Božić-Fredotović, K. \& Vidan, P., How nautical tourism ports affect the environment, Management of Natural Resources, Sustainable Development and Ecological Hazards, C.A. Brebbia, N. Jovanovic. \& E. Tiezzi, Wessex, Cape Town, pp. 123-133, 2009.

[2] Gračan, D., Doprinos nautičkog turizma strategiji razvoja hrvatskog turizma, Fakultet za turistički i hotelski menadžment, Opatija, 2002.

[3] Bartoluci, M., Čavlek, N., Turizam i sport, Fakultet za fizičku kulturu Sveučilišta u Zagrebu, Zagreb, 1998.

[4] Jadrešić, V., Nautički turizam, Pedagoška akademija Zadar, Institut za turizam, Zadar, 1978.

[5] Wikipedia, http://en.wikipedia.org/wiki/Nautical_tourism

[6] Favro S., Saganić I.: Sustainable development of nautical tourism in Croatia, New Perspectives and Values in World Tourism \& Tourism Management in the Future, Book 1, Turk-Kazakh International Tourism Conference, Alanya, pp. 602-620, 2006.,

[7] Robinson, P. J., Marinas and Social Demands, Australia, 2002. Online. http://www.icomia.com/library/introduction.asp (20.03.2008.),

[8] Favro, S., Joining of Croatia in the Development of the European Nautical Tourism, First European Yacht Tourism Congress, Rogoznica, 2002.

[9] Jolić N., Kavran Z., Ćavar I., ITS security levels multicriteria modelling for nautical ports, 4th International Conference on Ports and Waterways POWA 2009, Zagreb, 2009.

[10] Gračan D., Uran M.: The role of nautical tourism in the process of creating a Croatian competitive product, Proceedings of the 6th International Conference of the Faculty of Management Koper, Congress Centre Bernardin, Slovenia, 2005.

[11] Bošković, D., Favro S., Kovačić M., Evaluating the Significance of Nautical Tourism for Tourism and Economy, 25th International Conference on Organizational Science Development, Portorož, 2006. 